\title{
Metallographic techniques for the determination of the austenite grain size in medium-carbon microalloyed steels
}

\author{
C. García de Andrés*, M.J. Bartolomé, C. Capdevila, D. San Martín, \\ F.G. Caballero, V. López
}

\author{
Department of Physical Metallurgy, Centro Nacional de Investigaciones Metalúrgicas (CENIM), Consejo Superior de \\ Investigaciones Cientificas (CSIC), Avenida Gregorio del Amo, 8. E-28040 Madrid, Spain
}

Received 30 January 2001; accepted 6 April 2001

\begin{abstract}
Different techniques have been investigated to seek the best procedure to reveal the prior-austenite grain boundaries in three medium-carbon microalloyed steels. This study has been carried out over a wide range of temperatures $\left(950-1250^{\circ} \mathrm{C}\right)$ and it has been found that thermal etching (TE) is the best technique to reveal the prior-austenite grain boundaries in these steels. (C) 2001 Elsevier Science Inc. All rights reserved.
\end{abstract}

Keywords: Microalloyed steel; Thermal etching; Prior austenite grain size

\section{Introduction}

Due to its prominent influence on microstructure and mechanical, electrical, and magnetical properties, the accurate determination of the prior-austenite grain size (PAGS) of materials becomes of the greatest importance in metallurgical studies [1-3]. The determination of the PAGS involves, in principle, two distinct stages: revealing the austenite grain boundaries and measuring their size. At present, procedures for the grain size measurement are well known and reliable $[4,5]$. On the other hand, the process of revealing depends on the chemical composition of the steel, the given heat treatments, and other not well-identified factors. Therefore, this process could be difficult, especially in medium-carbon microal-

* Corresponding author. Tel.: +34-91-553-89-00 ext. 280; fax: +34-91-534-74-25.

E-mail address: cgda@cenim.csic.es (C. García de Andrés). loyed steels. In this sense, in recent years several metallographic investigations have been carried out in order to be able to determine the PAGS in microalloyed steels $[9,10]$. This has led to the development of many different methods of revealing the austenite grains boundaries; some of them are adaptable to general use and others are designed for a specific set of conditions. Two main methods are distinguished:

(i) Direct procedures based on the direct observation of austenitic microstructures at temperatures above the critical point, $A_{\mathrm{c} 3}$, by means of a high temperature microscope $[6,11-13]$.

(ii) Indirect procedures in which different metallographic techniques and postaustenitization heat treatments are used to visualize the grains at room temperature. In this sense, there are various indirect methods commonly used to reveal the prior-austenite grain (PAG):

- Chemical etching (CE) solutions are widely used [7,8,14-23,25-28]. Etching reagents based on saturated aqueous picric acid plus a wetting agent seem to give the best results in quenched and tem- 
pered steels $[7-10,15,17-19,21,25,26,28]$. Recently, details of a new general etchant $\left(10 \mathrm{~g}\right.$ of $\mathrm{CrO}_{3}, 50 \mathrm{~g}$ of $\mathrm{NaOH}, 1.5 \mathrm{~g}$ of picric acid, and $100 \mathrm{ml}$ of distilled water) for revealing PAG in steels have been published [9]. It was reported to be successful in samples of very different types of steel. However, it is relevant to point out that this solution is used hot $\left(120^{\circ} \mathrm{C}\right)$, and evolves toxic vapors.

- Another indirect method commonly used to reveal the PAG consists in the adjustment of the postaustenitization conditions needed to promote the formation of proeutectoid ferrite or cementite homogeneously precipitated at grain boundaries [7,8,23, 29-31]. A similar technique is used to reveal the PAG in eutectoid steels. In that case, austenite grain boundaries are outlined with pearlite [7,8,29-31]. Moreover, the carburization method by McQuaid and Ehn $[7,8,14,21-23,29-31]$ consists in the delineation of the austenite grain boundaries by the precipitation of a proeutectoid cementite network. The sample is austenitized, subsequently carburized at $925^{\circ} \mathrm{C}$ for $8 \mathrm{~h}$, and slowly cooled to room temperature.

- Oxidation etching [6,7,14,21-23,29-31,33] consists in heating a polished $2 \mathrm{~mm}$ wide surface of a sample in a furnace with an oxidizing atmosphere. The grain boundaries are revealed either by oxide accumulation or by grain-boundary decarburization.

- The thermal etching (TE) method [6,7,23,31, 34-36] consists in heating up to the austenitization temperature a sample with a finely polished $5 \mathrm{~mm}$ wide surface in a vacuum with a pressure of at least $1 \mathrm{~Pa}$ or in an inert atmosphere. Grooves form at the austenite grain boundaries by surface tension effects and matter transport mechanisms (evaporation-condensation, volume diffusion, and surface diffusion) [37-39]. After austenitization, samples are cooled down to room temperature.

In this work, all these techniques have been investigated to seek the best procedure to reveal the prior-austenite grain boundaries in three mediumcarbon microalloyed steels at austenitization temperatures ranging from $950^{\circ} \mathrm{C}$ to $1250^{\circ} \mathrm{C}$.

\section{Experimental procedure}

Three medium-carbon microalloyed steels with different vanadium and titanium content have been
Table 2

Austenitization conditions for HT1

\begin{tabular}{llc}
\hline Steel & T $\gamma\left({ }^{\circ} \mathrm{C}\right)$ & t $\gamma(\mathrm{s})$ \\
\hline $\mathrm{TiV}$ & $950,1000,1050,1100,1150,1200,1250$ & 60 \\
$\mathrm{~V}$ & $950,1000,1050,1100,1150,1200,1250$ & 180 \\
$\mathrm{Ti}$ & $950,1000,1050,1100,1150,1200,1225$, & 180 \\
& 1250 & \\
\hline
\end{tabular}

studied. Their chemical composition is listed in Table 1. Different combinations of heat treatments and etching reagents have been used in this investigation.

\subsection{Heat treatments}

\subsubsection{HT1 heat treatment}

Cylindrical samples $2 \mathrm{~mm}$ in diameter and $12 \mathrm{~mm}$ in length of the three steels were heat-treated in a very low thermal inertia radiation furnace at different heating temperatures in order to yield distinct PAGS. The power radiated by two tungsten filament lamps is focussed on the specimen by means of a bi-elliptical reflector. The temperature is measured with a $0.1-\mathrm{mm}$ diameter Chromel-Alumel (Type K) thermocouple spot welded to the specimen. Blowing a jet of helium gas directly onto the specimen surface carries out cooling. The helium flow rate during cooling is controlled by a proportional servovalve. These devices ensure an excellent efficiency in controlling the temperature and holding time of austenitization, and also ensure fast cooling $\left(>100^{\circ} \mathrm{C} / \mathrm{s}\right)$ in the quenching process. Specimens were austenitized in vacuum $(1 \mathrm{~Pa})$ at a heating rate of $5^{\circ} \mathrm{C} / \mathrm{s}$ at temperatures ranging from $950^{\circ} \mathrm{C}$ to $1250^{\circ} \mathrm{C}(\mathrm{T} \gamma)$ for different holding times (t $\gamma$ ) (Table 2). Finally, specimens were gas quenched to room temperature. A scheme of this heat treatment is shown in Fig. 1a.

\subsubsection{HT2, HT3, and HT4 heat treatments}

It is believed that the sensitivity of grain boundaries to chemical etchants can be improved by heating the samples in an oxidizing atmosphere [7,14,22,29, 30,32]. Moreover, it is known that some chemical etchants have the ability to reveal the austenite grain boundaries when they contain segregated elements such as phosphorus [6,24,32,40-42]. The tempering of quenched specimens can enhance this segregation. Thus, cubic samples of $5 \mathrm{~mm}$ in edge length of $\mathrm{Ti}$

Table 1

Chemical composition (wt.\%)

\begin{tabular}{lllllllllllll}
\hline Steel & $\mathrm{C}$ & $\mathrm{Mn}$ & $\mathrm{Si}$ & $\mathrm{P}$ & $\mathrm{Cr}$ & $\mathrm{Ni}$ & $\mathrm{Mo}$ & $\mathrm{V}$ & $\mathrm{Cu}$ & $\mathrm{Ti}$ & $\mathrm{Al}$ & $\mathrm{N}$ \\
\hline $\mathrm{TiV}$ & 0.37 & 1.45 & 0.56 & 0.01 & 0.04 & 0.07 & 0.03 & 0.11 & 0.14 & 0.015 & 0.02 & 0.02 \\
$\mathrm{~V}$ & 0.33 & 1.49 & 0.25 & 0.01 & 0.08 & 0.11 & 0.04 & 0.24 & 0.27 & 0.002 & 0.03 & 0.01 \\
$\mathrm{Ti}$ & 0.35 & 1.56 & 0.33 & 0.01 & 0.24 & 0.05 & 0.02 & 0.004 & 0.1 & 0.03 & 0.03 & 0.01 \\
\hline
\end{tabular}




\begin{tabular}{|c|c|c|c|c|c|}
\hline$\circlearrowright$ & $\mathbf{T}_{\gamma}, \mathbf{t}_{\gamma}$ & a) & $\begin{array}{l}\text { Table } \\
\text { Aust }\end{array}$ & ditions for HT6 & \\
\hline 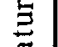 & & & Steel & $\mathrm{T} \gamma\left({ }^{\circ} \mathrm{C}\right)$ & $\mathrm{t} \gamma(\mathrm{s})$ \\
\hline & & & $\mathrm{TiV}$ & $1000,1100,1200$ & 60 \\
\hline & & & $\mathrm{V}$ & $1000,1100,1200$ & 180 \\
\hline & & & $\mathrm{Ti}$ & $1000,1100,1150$ & 180 \\
\hline
\end{tabular}

isothermally transformed at a temperature, $T_{\mathrm{ISO}}$, during a time, $t_{\text {ISO }}$. Finally, samples were quenched under helium gas flow. $T_{\mathrm{ISO}}$ and $t_{\mathrm{ISO}}$ are, respectively, the temperature and time required to outline the prioraustenite grain boundaries by the formation of allotriomorphic ferrite, a microstructure easy to reveal by CE. Those conditions were previously determined by means of a thorough study of the isothermal austenite decomposition for this steel.

\subsubsection{Thermal etching (HT6)}

Cylindrical samples $5 \mathrm{~mm}$ in diameter and $12 \mathrm{~mm}$ in length were used to reveal grain boundaries by the TE method. For that purpose, a $2 \mathrm{~mm}$ wide surface was generated along the longitudinal axis of samples by polishing and finishing with $1 \mu \mathrm{m}$ diamond paste. Later on, those samples were heat-treated in the radiation furnace described above. After reaching a vacuum pressure higher than $1 \mathrm{~Pa}$ (minimum value advised to avoid too much oxidation on the polished surface), samples were heated at a rate of $5^{\circ} \mathrm{C} / \mathrm{s}$ to the austenitization temperatures and then using the holding times listed in Table 3. Subsequently, samples

Table 4

Chemical etchants

\begin{tabular}{|c|c|}
\hline $\begin{array}{l}\text { Chemical } \\
\text { etchant }\end{array}$ & Description \\
\hline E1 & $\begin{array}{l}\text { Saturated aqueous picric acid + sodium } \\
\text { tridecylbenzene sulfonate } \\
\text { ( } 40 \% \text { by weight) as a wetting agent } \\
\text { (ASTM E 112-96). }\end{array}$ \\
\hline E2 & $\begin{array}{l}100 \mathrm{ml} \text { of distilled } \mathrm{H}_{2} \mathrm{O}+2 \mathrm{~g} \\
\text { of picric acid } \\
\left(\mathrm{C}_{6} \mathrm{H}_{3} \mathrm{~N}_{3} \mathrm{O}_{7}\right)+50 \mathrm{ml} \text { of } \\
\text { sodium alkylsulfonate ("Teepol") }+ \\
\text { drops of } \mathrm{HCl} \text {. The number of } \\
\mathrm{HCl} \text { drops varies between } 6 \text { and } 12 \text {. }\end{array}$ \\
\hline E3 & $\begin{array}{l}2 \% \text { Nital solution }\left(2 \mathrm{ml} \mathrm{HNO}_{3}+\right. \\
\left.98 \mathrm{ml} \text { of ethanol }\left(\mathrm{C}_{2} \mathrm{H}_{5} \mathrm{OH}\right)\right)\end{array}$ \\
\hline E4 & $\begin{array}{l}\text { Vilella's reagent. } 1 \mathrm{~g} \text { of picric acid }+ \\
5 \mathrm{ml} \text { of } \mathrm{HCl}+100 \mathrm{ml} \text { of ethyl alcohol. }\end{array}$ \\
\hline E5 & $\begin{array}{l}2 \mathrm{ml} \text { of } \mathrm{Br}+100 \mathrm{ml} \text { of } \\
\text { methyl alcohol }+ \text { drops of } \mathrm{HCl}\end{array}$ \\
\hline E6 & $\begin{array}{l}\text { Werner's etchant. } 3 \mathrm{~g} \text { of picric acid }+ \\
100 \mathrm{ml} \text { of xylene }+10 \mathrm{ml} \text { of ethyl alcohol }\end{array}$ \\
\hline E7 & $\begin{array}{l}\text { Picral. } 1 \mathrm{~g} \text { of picric acid, } 100 \mathrm{ml} \text { of } \\
\text { ethyl alcohol }+ \text { drops of } \mathrm{HCl} \text {. }\end{array}$ \\
\hline E8 & Picral+ Nital. \\
\hline
\end{tabular}

steel were heat-treated in an electrical furnace preheated in a nonprotected atmosphere to the austenitization temperatures, $\mathrm{T} \gamma$, (Table 2). After a holding time, $\mathrm{t} \gamma=180 \mathrm{~s}$ (Table 2), samples were quenched in water. A scheme of this heat treatment (HT2) is shown in Fig. 1b. Some of these samples were subsequently tempered at $450^{\circ}$ for $5 \mathrm{~h}$ (HT3) and others doubly tempered, first at $450^{\circ} \mathrm{C}$ for $5 \mathrm{~h}$ and later at $550^{\circ} \mathrm{C}$ for $5 \mathrm{~h}$ (HT4).

\subsubsection{HT5 heat treatment}

Another heat treatment, named HT5 (Fig. 1c), was carried out in the same radiation furnace mentioned above. Cylindrical samples $2 \mathrm{~mm}$ in diameter and 12 $\mathrm{mm}$ in length of TiV steel were heated at a constant rate of $5^{\circ} \mathrm{C} / \mathrm{s}$ to the austenitization conditions described in Table 2. Subsequently, samples were

Saturated aqueous picric acid + sodium sulfonate (ASTM E 112-96). of picric acid $\left(\mathrm{C}_{6} \mathrm{H}_{3} \mathrm{~N}_{3} \mathrm{O}_{7}\right)+50 \mathrm{ml}$ of sodium alkylsulfonate ("Teepol") + drops of $\mathrm{HCl}$. The number of $\mathrm{HCl}$ drops varies between 6 and 12 . $98 \mathrm{ml}$ of ethanol $\left.\left(\mathrm{C}_{2} \mathrm{H}_{5} \mathrm{OH}\right)\right)$ $5 \mathrm{ml}$ of $\mathrm{HCl}+100 \mathrm{ml}$ of ethyl alcohol. $2 \mathrm{ml}$ of $\mathrm{Br}+100 \mathrm{ml}$ of Werner's etchant. $3 \mathrm{~g}$ of picric acid+ Picral. $1 \mathrm{~g}$ of picric acid, $100 \mathrm{ml}$ of Picral + Nital. 
were cooled down to room temperature at a cooling rate of $1{ }^{\circ} \mathrm{C} / \mathrm{s}$. This last heat treatment was tested for all the steels and it is referred to as HT6.

\subsection{Metallographic preparation}

All the heat-treated samples, except those tested under HT6, were ground and polished using standard metallographic techniques. Reagents listed in Table 4 were used to reveal the prior-austenite grain boundaries. Most of them were unsatisfactory. Only chemical solutions E1, E2, and E3 gave positive results in some samples. The chemical etchants are able to reveal the prior-austenite grain boundaries because the chemical potential of grain boundaries is slightly higher than that of the crystal grains. A good chemical etchant can distinguish that small difference in potential.

Samples tested after TE (HT6) do not require metallographic preparation after heat treatment. The prior-austenite grain boundaries are revealed without CE.

The PAGS was measured on light optical micrographs using a linear intercept procedure [4,5]. The austenite grain size was represented by the mean grain diameter which was estimated by counting the number of grains intercepted by straight lines long enough to yield at least 50 intercepts in total.

\section{Results and discussion}

\subsection{Combination of heat treatments and chemical etchants}

The procedures evaluated to reveal the prioraustenite grain boundaries in the three studied steels are detailed as follows.

\subsubsection{TiV steel}

Most of the samples heat-treated according to HT1 and etched with reagents E1-8 had poor results. In this steel, only etchant E2 gave acceptable results for the two lowest austenitization temperatures $\left(950^{\circ} \mathrm{C}\right.$ and $\left.1000^{\circ} \mathrm{C}\right)$ as repeated polishing and etching cycles were carried out.

Table 5

Isothermal conditions for HT5

\begin{tabular}{lll}
\hline $\mathrm{T} \gamma\left({ }^{\circ} \mathrm{C}\right)$ & $T_{\text {ISO }}\left({ }^{\circ} \mathrm{C}\right)$ & $t_{\text {ISO }}(\mathrm{s})$ \\
\hline 1050 & 640 & 25 \\
1100 & 640 & 50 \\
1150 & 640 & 60 \\
1200 & 640 & 55 \\
1250 & 640 & 50 \\
\hline
\end{tabular}

Table 6

Revealing procedures and PAGS results

\begin{tabular}{|c|c|c|c|c|c|c|}
\hline \multirow[b]{2}{*}{$\begin{array}{l}\mathrm{T} \gamma \\
{ }^{\circ} \mathrm{C}\end{array}$} & \multicolumn{2}{|l|}{$\mathrm{TiV}$} & \multicolumn{2}{|l|}{$\mathrm{V}$} & \multicolumn{2}{|l|}{$\mathrm{Ti}$} \\
\hline & $\mathrm{HT} / \mathrm{CE}$ & $\begin{array}{l}\text { PAGS, } \\
\mu \mathrm{m}\end{array}$ & $\mathrm{HT} / \mathrm{CE}$ & $\begin{array}{l}\text { PAGS, } \\
\mu \mathrm{m}\end{array}$ & HT/CE & $\begin{array}{l}\text { PAGS, } \\
\mu \mathrm{m}\end{array}$ \\
\hline 950 & HT1/E2 & $8 \pm 1$ & HT1/E2 & $7 \pm 1$ & HT4/E2 & $13 \pm 2$ \\
\hline 1000 & HT1/E2 & $11 \pm 1$ & HT1/E2 & $8 \pm 1$ & HT4/E2 & $15 \pm 3$ \\
\hline 1050 & HT5/E3 & $27 \pm 3$ & HT1/E2 & $10 \pm 2$ & HT4/E2 & $16 \pm 2$ \\
\hline 1100 & HT5/E3 & $37 \pm 5$ & HT1/E2 & $25 \pm 3$ & a & $\mathrm{a}$ \\
\hline 1150 & HT5/E3 & $53 \pm 2$ & HT1/E2 & $34 \pm 6$ & $a$ & $a$ \\
\hline 1200 & HT5/E3 & $66 \pm 9$ & HT1/E2 & $58 \pm 14$ & HT4/E2 & $44 \pm 5$ \\
\hline 1225 & $\mathrm{~b}$ & $\mathrm{~b}$ & $\mathrm{~b}$ & $\mathrm{~b}$ & HT4/E2 & $57 \pm 10$ \\
\hline 1250 & HT5/E3 & $72 \pm 7$ & HT1/E2 & $121 \pm 32$ & HT4/E2 & $64 \pm 11$ \\
\hline
\end{tabular}

On the other hand, after some trial and error experiments, adequate isothermal conditions for HT5 could be established for the different austenitization temperatures. Temperatures and times listed in Table 5 correspond to the isothermal conditions required to outline the prior-austenite grain boundaries by the formation of allotriomorphic ferrite. The allotriomorphic ferrite along the grain boundaries was satisfactorily revealed by etchant E3. However, at the lowest austenitization temperatures $\left(950^{\circ} \mathrm{C}\right.$ and $1000^{\circ} \mathrm{C}$ ), difficulties were found to reveal the prior-austenite grain boundaries by this method. The PAGS is very fine at these temperatures and once ferrite is formed, those fine grains are immediately and totally covered and their size would be impossible to be accurately measured. Although this method (HT5) is quite reliable when good isothermal conditions are used, it requires considerable effort and experimentation. Table 6 shows the combination of heat treatments and chemical etchants (HT/CE) capable of revealing the austenite grain boundaries in TiV steel at the tested austenitization temperatures. This table also shows the PAGS results. Corresponding light optical micrographs of steel TiV are shown in Fig. 2.

\subsection{2. $V$ steel}

The combination of HT1 and etchant E2 was able to reveal the austenite grain boundaries in the whole range of austenitization temperatures tested (Table 2). Fig. 3 gives evidence of the success of this procedure to reveal the grain boundaries in steel V. Experimental results of the PAGS for this steel are listed in Table 6.

\subsubsection{Ti steel}

The combination of HT1 and etchant E2 in this steel revealed the austenite grain boundaries weakly, whereas martensite and inclusions were strongly etched. Repeated polishing and etching cycles were 

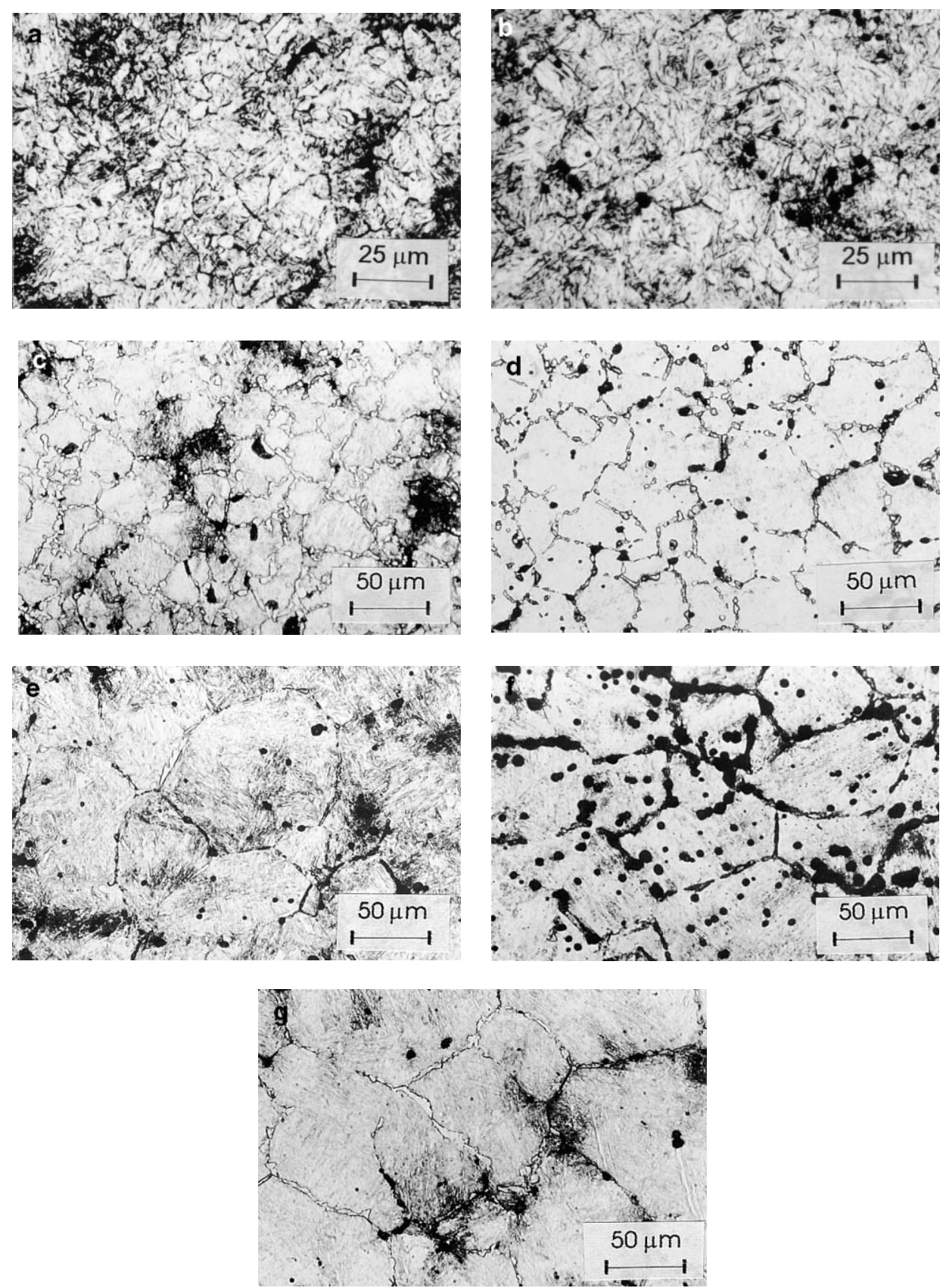

Fig. 2. Optical micrographs of the prior austenite grains at different austenitization temperatures in TiV steel revealed by the combination of $\mathrm{HT} 1$ and E2: (a) $950^{\circ} \mathrm{C}$ and (b) $1000^{\circ} \mathrm{C}$; and the combination of HT5 and E3: (c) $1050^{\circ} \mathrm{C}$, (d) $1100^{\circ} \mathrm{C}$, (e) $1150^{\circ} \mathrm{C}$, (f) $1200^{\circ} \mathrm{C}$, and (g) $1250^{\circ} \mathrm{C}$.

also tried, but only slight improvement was achieved. The microstructures obtained were not clear enough to assess the PAGS of this steel for any of the austenitization temperatures tested. Other etchants (E1, E3-8) were also tried, but none of them was successful.
Samples treated according to HT2 were etched with all the etchants listed in Table 4. Using the E2 solution and repeated polishing and etching cycles, some grain boundaries were visible for the lowest austenitization temperatures $\left(950^{\circ} \mathrm{C}\right.$ and $\left.1000^{\circ} \mathrm{C}\right)$. Although these results were better than those obtained 

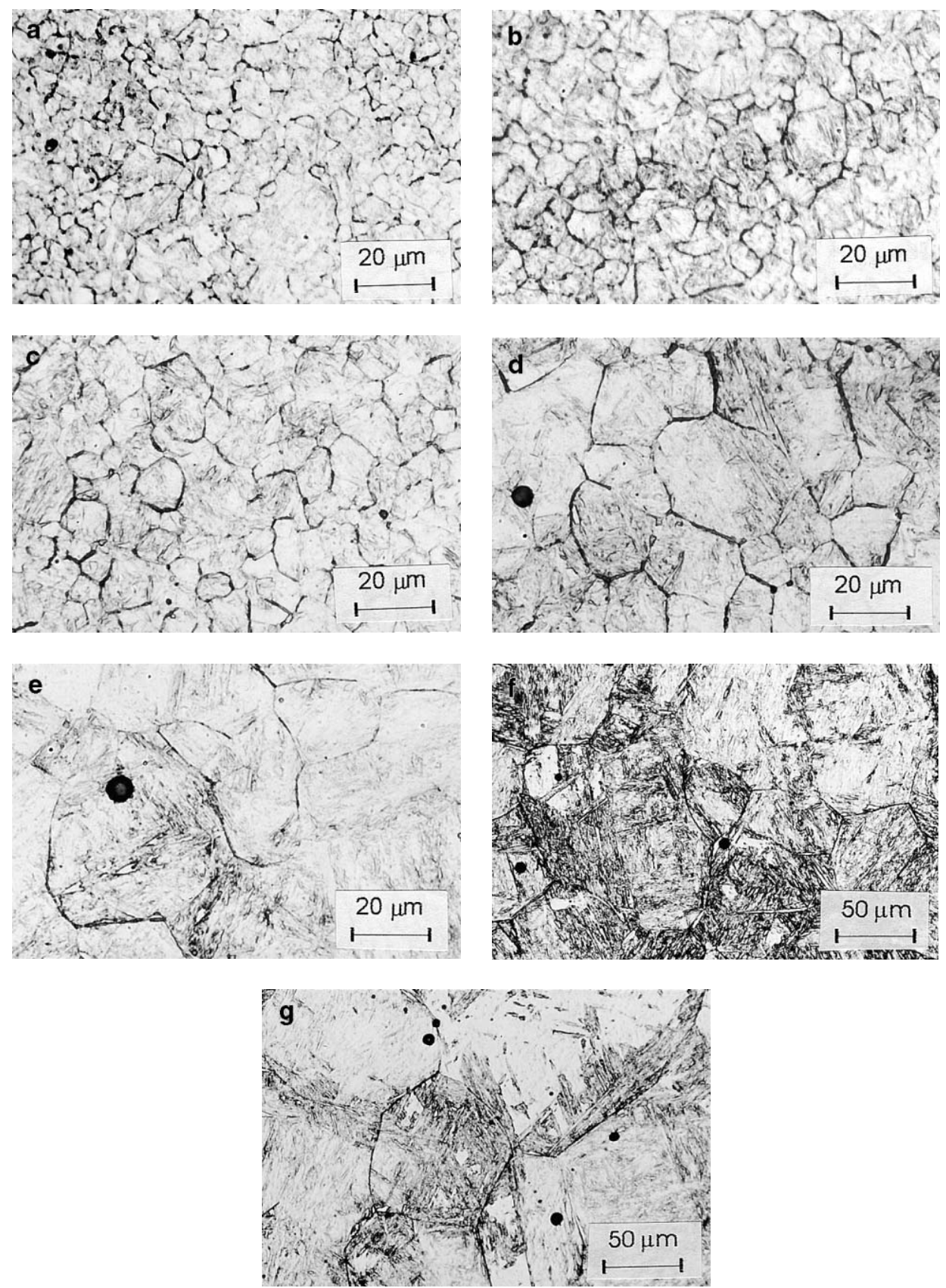

Fig. 3. Optical micrographs of the prior austenite grains at different austenitization temperatures in $\mathrm{V}$ steel revealed by the combination of $\mathrm{HT} 1$ and $\mathrm{E} 2$ : (a) $950^{\circ} \mathrm{C}$, (b) $1000^{\circ} \mathrm{C}$, (c) $1050^{\circ} \mathrm{C}$, (d) $1100^{\circ} \mathrm{C}$, (e) $1150^{\circ} \mathrm{C}$, (f) $1200^{\circ} \mathrm{C}$, and (g) $1250^{\circ} \mathrm{C}$.

with HT1, they were still not good enough to accurately measure the PAGS.

Specimens treated with HT2 were subsequently tempered according to HT3 and HT4 procedures. HT3 treatment and any of the different chemical etchants were not able to reveal the prior-austenite grain boundaries in this steel. However, the prior-austenite grain boundaries at low $\left(950^{\circ} \mathrm{C}\right.$, $\left.1000^{\circ} \mathrm{C}, 1050^{\circ} \mathrm{C}\right)$ and high $\left(1200^{\circ} \mathrm{C}, 1225^{\circ} \mathrm{C}\right.$, $1250^{\circ} \mathrm{C}$ ) austenitization temperatures were revealed adequately on samples treated under HT4 and repeatedly polished and etched with etchant E2. Micrographs in Fig. 4 show the results obtained by the combination of treatment HT4 and etchant 

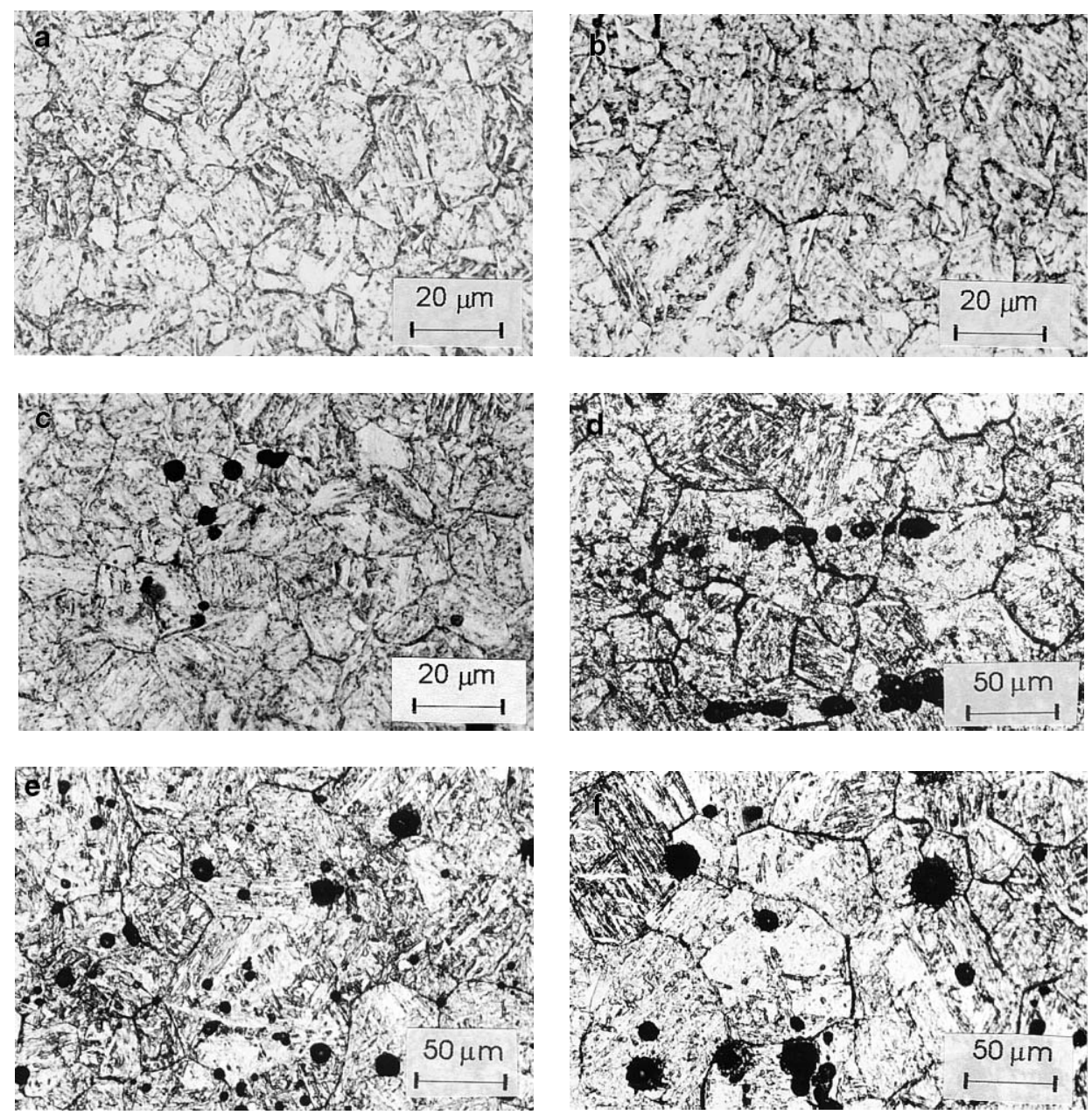

Fig. 4. Optical micrographs of the prior austenite grains at different austenitization temperatures in Ti steel revealed by the combination of HT4 and E2: (a) $950^{\circ} \mathrm{C}$, (b) $1000^{\circ} \mathrm{C}$, (c) $1050^{\circ} \mathrm{C}$, (d) $1200^{\circ} \mathrm{C}$, (e) $1225^{\circ} \mathrm{C}$, and (f) $1250^{\circ} \mathrm{C}$.

E2. PAGS values at those temperatures are shown in Table 6. PAGS could not be determined at intermediate temperatures $\left(1100^{\circ} \mathrm{C}\right.$ and $\left.1150^{\circ} \mathrm{C}\right)$ by this procedure.

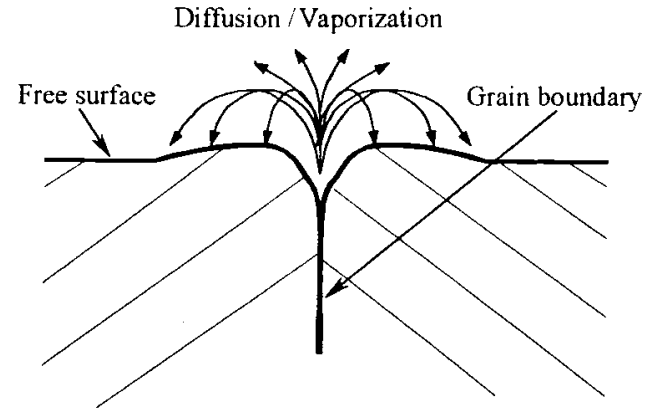

Fig. 5. Groove formed at the intersection of a free surface with a grain boundary.

\subsection{Thermal etching (HT6)}

It is known that at the intersection of a grain boundary with an initially flat surface, a local equilibrium is established between the surface tension at the free surface and the grain boundary [43]. This equilibrium is set up almost instanta-

Table 7

Measurements of the PAGS $(\mu \mathrm{m})$ revealed by CE and TE in steels $\mathrm{TiV}, \mathrm{V}$, and $\mathrm{Ti}$

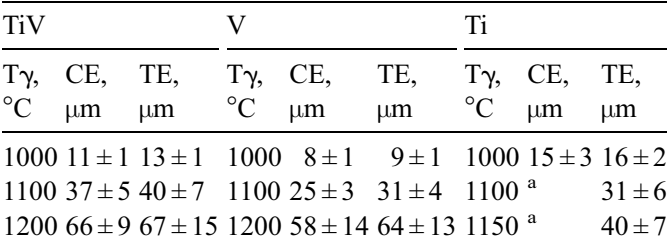

${ }^{a}$ Unsuccessful procedures. 

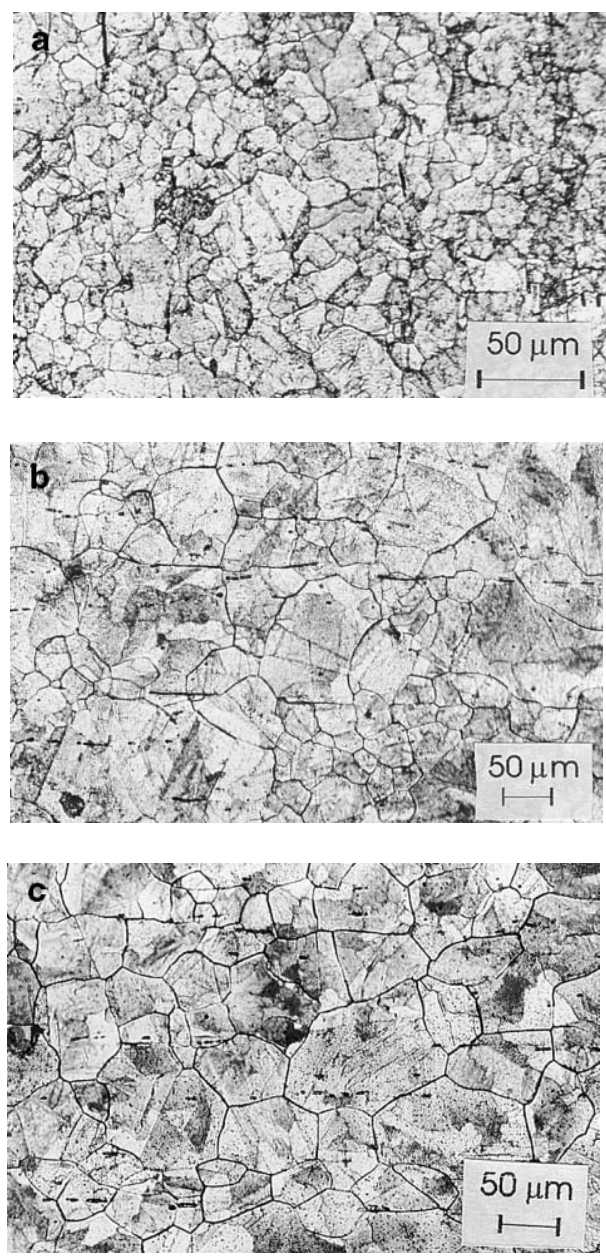

Fig. 6. Optical micrographs of the prior austenite grains at different austenitization temperatures in TiV steel revealed by TE: (a) $1000^{\circ} \mathrm{C}$, (b) $1100^{\circ} \mathrm{C}$, and (c) $1200^{\circ} \mathrm{C}$.

neously at high temperatures and the free surface adjacent to the line where the grain boundary emerges, becomes tightly curved as Fig. 5 shows. Grain boundary grooves are formed due to preferential transfer of material away from grain boundaries by matter transport mechanisms (evaporation-condensation, volume diffusion, and surface diffusion). Groove formation reveals the prioraustenite grain boundaries and thus, to determine the PAGS.

Table 7 lists PAGS values measured at different austenitization temperatures from samples treated according to $\mathrm{CE}$ and $\mathrm{TE}$ procedures. Figs. 6-8 show micrographs of the PAG revealed by TE at those temperatures in $\mathrm{TiV}, \mathrm{V}$, and $\mathrm{Ti}$ steels, respectively. This method has been successful at all the austenitization temperatures tested and for the three steels, even in Ti steel for intermediate temperatures $\left(1100^{\circ} \mathrm{C}\right.$ and $\left.1150^{\circ} \mathrm{C}\right)$, at which none of the other methods gave satisfactory results. As mentioned above, this method is rapid and practicable since no metallographic preparation is required after heat treatment. Moreover, it is worthy pointing out that a fully martensite microstructure is not necessary to reveal the prior-austenite grain boundaries by TE in contrast to other methods. Therefore, it could be used even for steels that are unable to form martensite by quenching.

In the microalloyed steels studied, ferrite and pearlite microstructures are obtained during slow cooling (e.g., $1{ }^{\circ} \mathrm{C} / \mathrm{s}$ ). From the comparison of the results in Table 7, it has been possible to confirm that the boundaries revealed by TE in those mixed microstructures really belong to the austenite grains. In fact, the PAGS results obtained by TE on slowly cooled samples are similar to those obtained by $\mathrm{CE}$
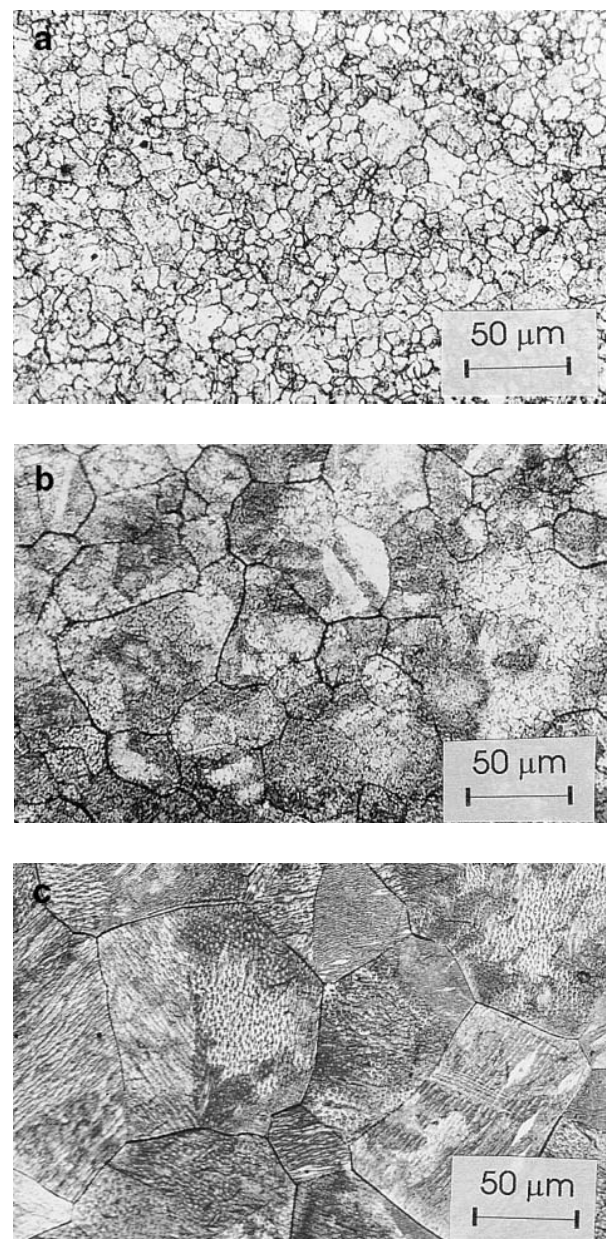

Fig. 7. Optical micrographs of the prior austenite grains at different austenitization temperatures in $\mathrm{V}$ steel revealed by TE: (a) $1000^{\circ} \mathrm{C}$, (b) $1100^{\circ} \mathrm{C}$, and (c) $1200^{\circ} \mathrm{C}$. 

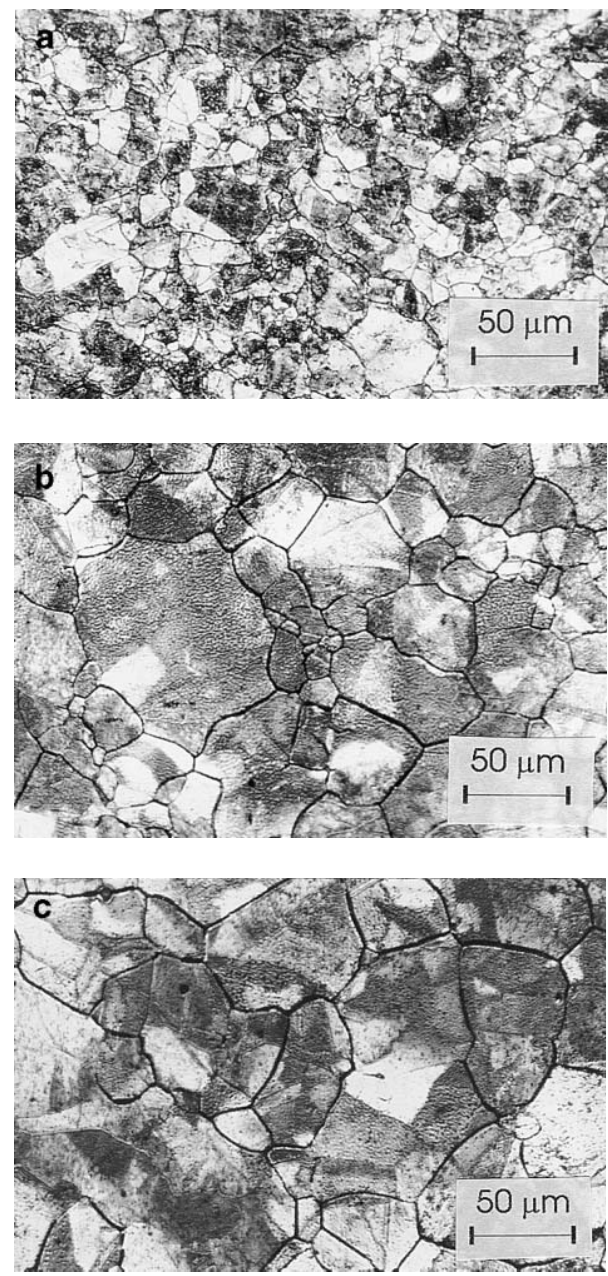

Fig. 8. Optical micrographs of the prior austenite grains at different austenitization temperatures in Ti steel revealed by TE: (a) $1000^{\circ} \mathrm{C}$, (b) $1100^{\circ} \mathrm{C}$, and (c) $1150^{\circ} \mathrm{C}$.

on quenched samples. Therefore, the austenite grain boundaries were revealed by TE even in samples with ferrite + pearlite microstructures.

\section{Conclusions}

(1) The tested procedures based on the combination of heat treatment and $\mathrm{CE}$ revealed the austenite grain boundaries for some steels in some austenitization conditions. However, these procedures have been unable to reveal the austenite grain boundaries for certain austenitization conditions in a given steel and for a particular condition in steels with similar chemical compositions. No rigorous explanation has been found concerning this fact.

(2) TE gave satisfactory results for the three microalloyed steels at all the austenitization condi- tions in which no other method was effective for revealing the prior-austenite grain boundaries. TE is the most adequate method for revealing the PAGS of the investigated microalloyed steels.

\section{Acknowledgments}

The authors acknowledge financial support from the Consejería de Educación y Cultura de la Comunidad de Madrid (SPAIN) (Project 07N/ 0065/1998).

\section{References}

[1] Ohtani H, Terasaki F, Kunitake T. The microstructure and toughness of high tensile strength steels. Trans ISIJ 1972;12:118-27.

[2] Petch NJ. The cleavage strength of polycrystals. J Iron Steel Inst Jpn 1953;174:25-8.

[3] Grange A. Strengthening steel by austenite grain refinement. Trans ASM 1966;59:26-48.

[4] Underwood EE. Quantitative stereology. Reading, MA: Addison-Wesley, 1970.

[5] Vander Voort GF. Metallography: principles and practice. New York: McGraw-Hill Book, 1984. pp. $440-65$.

[6] Vander Voort GF. Metallography: principles and practice. New York: McGraw-Hill Book, 1984. pp. $322-3$.

[7] Vander Voort GF. Metallography: principles and practice. New York: McGraw-Hill Book, 1984. pp. 219-23.

[8] Vander Voort GF. Metallography: principles and practice. New York: McGraw-Hill Book, 1984. pp. $435-40$.

[9] Zhang L, Guo DC. A general etchant for revealing prior-austenite grain boundaries in steels. Mater Charact 1993;30:299-305.

[10] Baldinger P, Posch G, Kneisslaas A. Revealing austenitic grains in microalloyed steels by picric acid etching. Pract Metallogr 1994;31:252-61.

[11] Lozinskii MG. High temperature metallography. Oxford, UK: Pergamon, 1961. p. 241.

[12] Okamoto M, Miyagawa O, Saga T. High temperature microscope observation of the austenite grain size of steels. Trans Jpn Inst Met 1966;7:217-23.

[13] Modin H, Modin S. Metallurgical microscopy. London, UK: Butterworths, 1973. pp. 181-3.

[14] Modin H, Modin S. Metallurgical microscopy. London, UK: Butterworths, 1973. p. 175.

[15] Wiedermann J, Wojtas J, Stepien J. Etchant for revealing prior austenite grain in alloy steel. Pract Metallogr 1988;25:449-55.

[16] Leitner S, Köstler HJ. Investigations into the application of etching reagents for austenite grain boundaries in tempered high-speed steels. Pract Metallogr 1978; 15:66-77. 
[17] Brownrigg A, Curcio P, Boelen R. Etching of prior austenite grain boundaries in martensite. Metallography 1975;8:529-33.

[18] Bodnar RL, McGraw VE, Brandemarte AV. Technique for revealing prior austenite grain boundaries in $\mathrm{CrMoV}$ turbine rotor steel. Metallography 1984;17:109-14.

[19] Jiang X, Zhou Y. The role of surface active agents on etching grain boundaries in steels. Pract Metallogr 1987;24:521-34.

[20] Champman BH, Cooke MA, Thompson SW. Austenite grain size refinement by thermal cycling of a low-carbon, copper-containing martensitic steel. Scr Metall 1992;26:1547-52.

[21] Schacht E, Richter J. Experiences with etching reagents to show former austenite grain boundaries in steels. Pract Metallogr 1998;35:384-95.

[22] Vilella JR. Metallographic technique for steel. Metals Park, Cleveland, OH: American Society for Metals, 1938. pp. 26-52.

[23] Krauss G. Steels: heat treatment and processing principles. Materials Park, OH: ASM International, 1988. pp. $188-93$.

[24] Krauss G. Steels: heat treatment and processing principles. Materials Park, OH: ASM International, 1988. pp. 236-9.

[25] Béchet S, Beaujard L. Nouveau réactif pour la mise en évidence micrographique du grain austénitique de aciers trempés ou trempés-revenus. Rev Mét 1955;10: $830-6$.

[26] Dreyer GA, Austin DE, Smith WD. New etchant brings out grain boundaries in martensitic steels. Met Prog 1964;86:116-7.

[27] Miller OO, Day MJ. Ferric chloride etchant for austenite grain size of low-carbon steel. Met Prog 1949;56:692-5.

[28] Grange RA. The rapid heat treatment of steel. Metall Trans 1971;2:65-78.

[29] Riedl R. A suggestion for the consistent determination of austenite grain size. Pract Metallogr 1978;15: $537-41$.
[30] Riedl R. The determination of austenite grain size in ferrous alloys. Metallography 1981;14:119-28.

[31] Sinha AK. Ferrous physical metallurgy. Stoneham, MA: Butterworth Publishers, 1989. pp. 315-7.

[32] Sinha AK. Ferrous physical metallurgy. Stoneham, MA: Butterworth Publishers, 1989. pp. 574-6.

[33] Tobin H, Kenyon RL. Austenite grain size of eutectoid steel. Trans ASM 1938;26:133-52.

[34] Halliday WI. Determination of the austenite grain size of steel using a thermal etching method. ISI Special Report No 81, Iron and Steel Inst., London, UK, 1963, pp. $65-7$.

[35] Day MJ, Austin JB. Heat etching as a means of revealing austenite grain size. Trans ASM 1940;28: $354-71$.

[36] Miller OO, Day MJ. Heat etching as a general method for revealing the austenite grain size of steels. Trans ASM 1942;30:541-68.

[37] Mullins WW. Theory of thermal grooving. J Appl Phys 1957;28:333-9.

[38] Mullins WW. Grain boundary grooving by volume diffusion. Trans Metall Soc AIME 1960;218: $354-61$.

[39] Srinivasan SR, Trivedi R. Theory of grain boundary grooving under the combined action of the surface and volume diffusion mechanisms. Acta Metall 1973;21: 611-20.

[40] Ucisik AH, McMahon CJ, Feng HC. The influence of intercritical heat treatment on the temper embrittlement susceptibility of a p-doped $\mathrm{Ni}-\mathrm{Cr}$ steel. Metall Trans 1978;9A:321-9.

[41] Olefjord I. Temper embrittlement. Int Met Rev 1978; 23:149-63.

[42] Cohen JB, Hurlich A, Jacobson M. A metallographic etchant to reveal temper brittleness in steel. Trans ASM 1947;39:109-38.

[43] Porter DA, Easterling KE. Phase transformation in metals and alloys. London, UK: Chapman \& Hall, 1992. pp. 124-30. 